\title{
KSZTAŁTOWANIE SIĘ RELACJI MIĘDZY PAŃSTWEM A KOŚCIOŁEM. ASPEKT HISTORYCZNO-PRAWNY
}

DOI: http://dx.doi.org/10.12775/TiCz.2018.004

\section{WSTĘP}

Refleksja, która zostaje podjęta, dotyczyć będzie problematyki kształtowania się relacji, jaka od wieków zachodzi między dwiema współistniejącymi ze sobą wspólnotami, do których przynależą ci sami ludzie, czyli między Kościołem a państwem.

Kościół to wspólnota wiernych hierarchicznie zorganizowana, której celem jest służba ludziom i niesienie pomocy w osiągnięciu podstawowych wartości religijnych i etycznych, a także doprowadzenie każdego ze swoich członków do rzeczywistości nadprzyrodzonej, czyli do zbawienia. Państwo to społeczność utworzona przez ludzi, zazwyczaj należących do tej samej wspólnoty kulturowej, której celem jest zaspokojenie swoich potrzeb doczesnych. Są to dwie wspólnoty ludzkie, których nie da się

* Ks. Krzysztof Rogala - prezbiter diecezji włocławskiej. Uzyskał tytuł magistra teologii w roku 2011 na Wydziale Teologicznym UMK w Toruniu. W roku 2015 uzyskał tytuł magistra prawa kanonicznego na Wydziale Prawa Kanoniczego UKSW w Warszawie, obecnie doktorant tegoż wydziału. Od roku 2015 jest obrońcą węzła małżeńskiego w Sądzie Kościelnym Diecezji Włocławskiej (rogalakrzysztof@wp.pl). 
wyraźnie oddzielić od siebie, gdyż w ich skład wchodzą te same osoby. Dlatego od wieków rodziła się potrzeba ustalenia właściwej relacji miedzy Kościołem a państwem, jako społecznościami odmiennej natury. Niniejsze opracowanie ukaże nam w porządku chronologicznym, w jaki sposób kształtowały się te relacje od czasu założenia przez Chrystusa wspólnoty Kościoła aż do czasów współczesnych.

\section{POCZĄTKI DUALIZMU W RELACJI PAŃSTWO-KOŚCIÓł}

Za czasów ziemskiej działalności Chrystusa państwa antyczne występujące w basenie Morza Śródziemnego charakteryzowały się monizmem religijno-politycznym. Ważnym aspektem tego monizmu było utożsamianie władzy politycznej z władzą religijną. Monarcha bądź inny przywódca państwowy był także przywódcą w znaczeniu religijnym i uważany był za najwyższego kapłana. Cesarzowi rzymskiemu przypisywano boskie atrybuty i odbierał cześć jako bóg. Wszystkie religie z narodów podbitych przez imperium rzymskie, z wyjątkiem Izraela, charakteryzowały się politeizmem, dlatego nie było dla nich problemem oddawanie boskiej czci cesarzowi. Kult cesarza sprzyjał integracji politycznej narodów wchodzących w skład cesarstwa rzymskiego' ${ }^{1}$.

Państwa antyczne charakteryzowały się dwiema wersjami monizmu religijno-politycznego. Na Wschodzie monizm polegał na hierokracji, czyli dominacji pierwiastka religijnego nad politycznym. Przykładem takiego państwa było państwo żydowskie, którego prawo opierało się na Starym Testamencie. Natomiast druga wersja monizmu występowała na Zachodzie, a przykładem państwa, w którym obowiązywał, jest cesarstwo rzymskie. W tej wersji pierwiastek religijny ustępował miejsca strukturom politycznym, a religia była instrumentem politycznym² ${ }^{2}$

Dopiero pojawienie się chrześcijaństwa, które stanowiło religię uniwersalną, niezależną od władzy państwowej, odcinającą się od świata żydowskiego, a także pogańskiego, która nie była ograniczona żadnymi s. 15 .

1 J. Krukowski, Kościelne prawo publiczne. Prawo konkordatowe, Lublin 2013, 2 Tamże. 
granicami państwowymi, a jej wyznawcą mógł zostać każdy człowiek, bez względu na pochodzenie czy stan społeczny, wprowadziło nową koncepcję w relacji między religią a polityką państwową, którą nazwano dualizmem chrześcijańskim. Podstawą tej nowej koncepcji stały się słowa założyciela nowej religii - Chrystusa, który poleca „oddawać cesarzowi to, co cesarskie, a Bogu to, co boskie"3. Te słowa oznaczały, iż należy oddzielić rzeczywistość polityczną od rzeczywistości religijnej ${ }^{4}$ Słowa Chrystusa wskazały, że nie wolno utożsamiać cesarza z Bogiem oraz że należy oddzielić obowiązki ludzkie względem Boga i względem władcy doczesnego, reprezentowanego w osobie cesarza. Chrześcijaństwo zdecydowanie odrzuciło istniejącą do tej pory zasadę monizmu religijno-politycznego na rzecz dualizmu religijno-politycznego ${ }^{5}$; tym samym rozpoczął się nowy etap w kształtowaniu stosunków między państwem a religią.

Jako pierwsi nową zasadę zaczęli w praktyczny sposób wprowadzać Apostołowie oraz pierwsi chrześcijanie. Byli oni wiernymi świadkami i wyznawcami swojej nowej religii, ale pozostawali przy tym wiernymi i lojalnymi obywatelami państwa, do którego przynależeli w rzeczywistości doczesnej. Wypełniając swoje obowiązki względem prawa państwowego, odnosząc się do cesarza z szacunkiem, a także modląc się za niego, mieli świadomość, iż nie jest on ich jedynym władcą, gdyż posiadali swoich przełożonych w rzeczywistości nadprzyrodzonej, czyli hierarchów kościelnych ${ }^{6}$. Chrześcijanie odznaczali się lojalnością i posłuszeństwem względem władców doczesnych, chyba że wydawali polecenia dotyczące przepisów religijnych, wówczas odmawiali im posłuszeństwa?

Chrześcijanie, jako wyznawcy jednej religii, tworzą wspólnotę założoną przez Chrystusa, zwaną Kościołem. W każdej społeczności potrzebny jest porządek prawny. Wprowadzenie dualizmu religijno-politycznego przyczyniło się do powstania odrębnego od państwowego porządku prawnego - kościelnego. Prawo kościelne, które swoje źródło

3 Mt 22,21.

${ }^{4}$ W. Góralski, Wstęp do prawa wyznaniowego, Płock 2003, s. 9-10.

${ }^{5}$ J. Krukowski, Kościelne prawo publiczne, s. 16-17.

6 R. Sobański, Prawo kościelne a prawo świeckie, „Prawo Kanoniczne” 30 (1987) 3-4, s. 64-65.

7 K. Rahner, Kościót i prawo we wczesnym chrześcijaństwie, Warszawa 1986, s. 21-23. 
i podstawy zawiera $\mathrm{w}$ religii i wynikającej z niej moralności, swoim zasięgiem obejmuje tych samych ludzi, którzy w porządku doczesnym podlegają prawu cesarstwa ${ }^{8}$.

Podstawą dualizmu chrześcijańskiego stało się rozróżnienie dwóch porządków, duchowego i doczesnego. Konsekwencją takiego podziału stało się ograniczenie władzy cesarskiej względem tego, co dotyczyło zasad życia religijnego. Było to początkiem procesu odejścia od obowiązującego dotychczas porządku prawnego oraz społeczno-religijnego. W wyniku nieprzestrzegania przez chrześcijan zasad religijnych obowiązujących w cesarstwie rozpoczęły się ich prześladowania, które trwały od cesarza Nerona (68 r. n.e.) aż do cesarza Dioklecjana (285-305 r.). Chrześcijanie byli traktowani jako wyznawcy religii prawnie zabronionej i mimo że posiadali własną strukturę kościelną, różną od państwowej, to nie mogli cieszyć się wolnością i tolerancjąa

\section{2. ŚREDNIOWIECZNE KSZTAŁTOWANIE SIĘ RELACJI RELIGIJNO- POLITYCZNYCH}

W roku 313 dwaj cesarze rzymscy, ogłoszeniem edyktu mediolańskiego, dokonali przełomu w relacji między państwem a Kościołem. Edykt mediolański przyczynił się do normalizacji stosunków pomiędzy cesarstwem rzymskim oraz Kościołem katolickim. Najważniejszymi postulatami tego dokumentu były:

uznanie przez państwo wolności religijnej - a nie tylko tolerancji dla chrześcijan na zasadzie równości z wyznawcami innych religii [...]; uznanie wolności religijnej w wymiarze instytucjonalnym, tzn. uznanie Kościoła w państwie rzymskim jako struktury odrębnej od struktur państwowych [...]; celem, jaki został wskazany przez cesarzy - autorów edyktu, było osiągnięcie pokoju wewnątrz państwa i wyjednanie przychylności ze strony najwyższego Boga, bez wyraźnego wskazania, czy chodzi o Boga chrześcijan ${ }^{10}$.

\footnotetext{
8 W. Góralski, Wstęp do prawa wyznaniowego, s. 10.

9 M. Banaszak, Historia Kościoła Katolickiego, t. 1, Warszawa 1989, s. 111-115.

${ }^{10}$ J. Krukowski, Kościelne prawo publiczne, s. 21-22.
} 
Wprowadzenie dualizmu chrześcijańskiego okazało się procesem bardzo trudnym, gdyż napotykało na wiele problemów od strony władzy państwowej, jak i kościelnej, zwłaszcza jeśli chodziło o zakres kompetencji. Pojawiła się pokusa powrotu do monizmu, ale w wydaniu chrześcijańskim, co zaowocowało cezaropapizmem, a później teokracją papieską. Jednak koncepcja dualizmu chrześcijańskiego nigdy nie została zaniechana ${ }^{11}$.

Następcy cesarza Konstantyna doprowadzają do coraz bardziej ścisłego powiązania relacji państwowych z kościelnymi, z widoczną tendencją do uzależnienia władzy kościelnej od państwowej. W roku 380 cesarz Teodozjusz Wielki ogłasza chrześcijaństwo jako oficjalną religię państwową. Jest to rozwój prawodawstwa kościelnego, zyskuje ono na znaczeniu i w pewnym sensie zaczyna łączyć się z prawem świeckim. Chrześcijanie dalej pozytywnie odnosili się do prawa świeckiego, nie przestrzegali tylko tych ustaw, które kłóciły się z wolą Bożą ${ }^{12}$.

\subsection{CEZAROPAPIZM}

Jest to system jaki powstał między państwem a Kościołem, w którym władza państwowa rości sobie prawo do dominacji nad władzą kościelną. Państwo pragnie ingerować, nadzorować i kontrolować wszystko, co jest związane $\mathrm{z}$ działalnością kościelną nie tylko od strony zewnętrznej, ale także chce mieć wpływ na sprawy wewnętrzne. Początkowo taki system ukształtował się na Wschodzie w cesarstwie bizantyjskim, a później na Zachodzie w cesarstwie rzymskim w wydaniu frankońskim, a następnie germańskim $^{13}$.

\subsubsection{CEZAROPAPIZM BIZANTYJSKI}

Wyrażał się w całkowitym podporządkowaniu Kościoła władzy państwowej. Stosowano środki przymusu w celu zagwarantowania jedności pomiędzy państwem a religią, co w konsekwencji doprowadziło do

\footnotetext{
11 Tenże, Kościót i państwo. Podstawy relacji prawnych, Lublin 1993, s. 19.

12 W. Góralski, Wstęp do prawa wyznaniowego, s. 11-13.

${ }^{13}$ J. Krukowski, Kościół i państwo, s. 22.
} 
nietolerancji wobec wyznawców innej religii niż chrześcijaństwo ${ }^{14}$. Ten rodzaj cezaropapizmu spowodował powstanie państwa wyznaniowego chrześcijańskiego ${ }^{15}$. System ten przyczynił się do schizmy wschodniej (1054). Po upadku wschodniego cesarstwa rzymskiego (1452) cezaropapizm bizantyjski przetrwał w państwach Europy Wschodniej, które chrześcijaństwo przyjęły od Bizancjum ${ }^{16}$.

\subsubsection{CEZAROPAPIZM ZACHODNI}

Kiedy upadło Cesarstwo Zachodnie (476), Kościół katolicki z papieżem na czele podjął się misji ewangelizacyjnej barbarzyńskich ludów, które przybyły do Europy. Przekazywano im ewangelię oraz prawo rzymskie. W ten sposób powstała nowa rzeczywistość religijno-polityczna, która nazywała się Święte Cesarstwo Rzymskie. Zachowano dualizm religijno-polityczny w postaci dwóch odrębnych władz w osobach papieża i cesarza, każdego suwerennego w swoim porządku. Jednak cesarze dążyli do przejęcia władzy nad Kościołem. Dlatego na Zachodzie również pojawił się cezaropapizm. Pierwsza wersja była w wydaniu frankońskim. Początkiem była koronacja króla Franków Karola Wielkiego na cesarza w Rzymie (800) ${ }^{17}$. Nowy cesarz postawił sobie dwa cele: niesienie pomocy Kościołowi od wewnątrz, a także ochrona Kościoła od zewnątrz przed atakami pogan i heretyków. Mimo że cesarz respektował władzę papieską, w praktyce dążył do ograniczenia roli papieża tylko do modlitwy o pomyślność dla Kościoła i cesarstwa ${ }^{18}$.

Po upadku cesarstwa frankońskiego centrum władzy politycznej na terenie Europy przeniosło się do państw germańskich. Początkiem nowej wersji cezaropapizmu zachodniego (germańskiego) była koronacja księcia Ottona I na cesarza, której dokonał papież Jan XII (962) ${ }^{19}$. Cesarze germańscy, w dużo większym stopniu niż cesarze frankońscy, dążyli do

\footnotetext{
${ }^{14}$ R. Sobański, Kościół jako podmiot prawa, Warszawa 1983, s. 179-180.

15 J. Krukowski, Polskie prawo wyznaniowe, Warszawa 2008, s. 28.

16 Tenże, Kościół i państwo, s. 23-24.

17 M. Banaszak, Historia Kościoła Katolickiego, s. 32.

18 J. Krukowski, Polskie prawo wyznaniowe, Warszawa 2008, s. 28-29.

19 W. Góralski, Wstęp do prawa wyznaniowego, s. 15.
} 
supremacji nad Kościołem. Świeccy władcy nadawali urzędy kościelne, a w szczególności biskupie i opackie, oraz beneficja, często przy tym pomijając władzę papieską. Cesarze dopuszczali się interwencji w życie wewnętrzne Kościoła i chcieli podporządkować sobie papieża ${ }^{20}$.

\subsection{ODPOWIEDŹ KOŚCIOŁA NA STANOWISKO CEZAROPAPIZMU}

Kościół wobec cezaropapizmu przyjął strategię dwuetapową. Najpierw była to postawa obronna (IV-X wiek), a następnie ofensywna (XI-XIII wiek). Pierwszy etap polegał na zasadzie poszanowania autonomii dwóch władz, duchowej i doczesnej. W obronie dualizmu chrześcijańskiego występowali już ojcowie Kościoła tacy jak św. Ambroży (†397) i św. Augustyn (†430). Jednak podstawę doktryny obronnej ukształtował papież Galezy I (492-496), który w liście do cesarza Anastazego w 494 roku wystąpił przeciwko polityce podporządkowywania władzy religijnej przez władzę państwową. Głównymi tezami Galezego I były: rozróżnienie dwóch najwyższych władz rządzących życiem społecznym, duchowej - papież i doczesnej - cesarz; zależność władzy doczesnej od duchowej w sprawach natury duchowej, a także zależność władzy duchowej od doczesnej w sprawach doczesnych; rozróżnienie kompetencji cesarza co do spraw ziemskich i papieża co do spraw duchowych; zakaz koncentracji obu władz w tym samym podmiocie ${ }^{21}$. Takie stanowisko Kościoła przejęli kanoniści, z Gracjanem na czele, a później także i św. Tomasz z Akwinu²2.

Jeśli chodzi o drugi etap walki z cezaropapizmem (XI-XIII w.), to polegał on na „teorii bezpośredniej władzy w porządku doczesnym”; nazwany był także systemem teokracji papieskiej ${ }^{23}$. Według tej teorii papież posiada podwójną władzę, duchową w porządku religijnym i doczesną w porządku ziemskim. Religijną sprawuje osobiście, a doczesną powierza

20 A. Mezglewski, Systemy relacji państwo-kościół w ujęciu historycznym, w: Prawo wyznaniowe, red. A. Mezglewski, H. Misztal, P. Stanisz, wyd. 3, Warszawa 2011, s. $14-15$.

${ }^{21}$ J. Krukowski, Kościelne prawo publiczne, s. 31-33.

${ }^{22}$ W. Góralski, Wstęp do prawa wyznaniowego, s. 16.

${ }^{23}$ H. Misztal, Systemy relacji państwo-Kościół, w: Prawo wyznaniowe, red. H. Misztal, P. Stanisz, wyd. 2, Lublin 2003, s. 31. 
cesarzowi, ale w każdej chwili, jeśli cesarz pobłądzi, to może zostać tej władzy pozbawiony ${ }^{24}$. Do upowszechnienia się tej teorii przyczynili się tacy papieże jak: Grzegorz VII (1073-1075), Innocenty III (1198-1215), Innocenty IV (1243-1274) i Bonifacy VIII (1294-1303) ${ }^{25}$. Głównymi założeniami tej teorii były: idea jednej społeczności chrześcijańskiej, którą utożsamiano z Kościołem i z państwem; dualizm religijno-polityczny, który polegał na rozróżnieniu dwóch władz najwyższych w swoim porządku (papież - religia, cesarz - państwo), został zredukowany do przyjęcia tezy o pełnej władzy papieża w obu dziedzinach; władza świecka nie może ingerować w sprawy wewnętrzne Kościoła; mimo iż władza świecka nie może wtrącać się w sprawy Kościoła, to ma obowiązek użyć swoich środków przymusu dla udzielenia pomocy Kościołowi dla realizacji jego celów; Prawo Boże, a także kanoniczne, jest wyższe od jakiejkolwiek ustawy świeckiej ${ }^{26}$.

Tak ukształtowana teoria bezpośredniej władzy papieskiej, która reprezentowała skrajną zasadę dualizmu chrześcijańskiego, nie mogła przetrwać próby czasu ${ }^{27}$. Była ona zjawiskiem tylko przejściowym ${ }^{28}$, tym bardziej że zaczęła zmieniać się sytuacja polityczna na terenie Europy. Powstawały nowe suwerenne państwa i to one zaczęły nowe kształtowanie się relacji między religią a państwem ${ }^{29}$.

\section{EPOKA NOWOŻYTNA I ROZPAD JEDNOŚCI RELIGIJNO-POLITYCZNEJ W CHRZEŚCIJAŃSKIEJ EUROPIE}

Epoka nowożytna przynosi nową sytuację polityczną na mapie Europy. Głównym bodźcem staje się reformacja (XV w.); przyczynia się ona do podziałów religijnych i politycznych. Pojawiają się nowe Kościoły protestanckie, które zrywają swoją jedność ze Stolicą Apostolską. Zwłaszcza dotyczyło to Kościołów na terenach państw germańskich. Podział

${ }^{24}$ J. Krukowski, Polskie prawo wyznaniowe, s. 29.

${ }^{25}$ W. Góralski, Wstęp do prawa wyznaniowego, s. 16.

${ }^{26}$ J. Krukowski, Kościelne prawo publiczne, s. 34-36.

27 W. Góralski, Wstęp do prawa wyznaniowego, s. 18.

${ }^{28}$ J. Krukowski, Kościelne prawo publiczne, s. 36.

29 W. Góralski, Wstęp do prawa wyznaniowego, s. 18-19. 
polityczny dotyczył powstania wielu suwerennych państw wyznaniowych, których władcy przypisywali sobie władzę nad Kościołem. Nurt ten został nazwany jurysdykcjonalizmem, który w założeniu stał się nową wersją cezaropapizmu, $\mathrm{z}$ tą różnicą, że uznawał istnienie dwóch źródeł władzy, ale świecka dominowała nad duchową. Występował w dwóch postaciach, protestanckiej i katolickiej ${ }^{30}$.

Jeśli chodzi o jurysdykcjonalizm protestancki, to władcy świeccy państw protestanckich przypisywali sobie całkowitą władzę nad sprawami kościelnymi w każdej jego dziedzinie zarówno zewnętrznej, jak i wewnętrznej. System ten nazywany jest teokracją świecką ${ }^{31}$. Władcy protestanccy przypisywali sobie także możliwość modyfikacji dogmatycznych prawd wiary ${ }^{32}$.

Jeśli chodzi o jurysdykcjonalizm w wersji katolickiej, to nie był on tak skrajny jak protestancki. Władcy państw katolickich przypisywali sobie prawo do opieki nad Kościołem. Nie ingerowali w jego sprawy doktrynalne, ale w zamian rościli sobie prawo do ingerencji w sprawy wewnętrzne, ograniczając przy tym wpływy Stolicy Apostolskiej w nominacje biskupów, cenzurę pism kościelnych, kontrolę nad stowarzyszeniami, a także ingerencję we władzę sądowniczą. Najbardziej skrajna wersja jurysdykcjonalizmu katolickiego, zwana gallikanizmem, występowała we Francji ${ }^{33}$. Ponadto system ten obejmował swoim zasięgiem takie kraje jak: Włochy, Hiszpanię, Austrię, państwa katolickie niemieckie ${ }^{34}$.

Kościół musiał przyjąć nowe stanowisko, aby obronić się przed zapędami władców świeckich nad sprawowaniem władzy duchowej. Przyjęto zatem zmodyfikowaną wersję dualizmu chrześcijańskiego w postaci pośredniej władzy Kościoła w porządku doczesnym. Jedną z podstaw tej teorii stała się potrzeba rozwiązania problemu dotyczącego uprawnień papieża względem do osób niewierzących zamieszkujących nowo odkry-

${ }^{30}$ A. Miziński, Relacje między państwem a kościołem na Soborze Watykańskim II, w: Katolickie zasady relacji państwo-Kościół a prawo polskie, red. J. Krukowski, M. Sitarz, H. Stawniak, Lublin 2015, s. 49.

31 J. Krukowski, Polskie prawo wyznaniowe, s. 29-30.

32 W. Góralski, Wstęp do prawa wyznaniowego, s. 20.

33 J. Krukowski, Polskie prawo wyznaniowe, s. 30.

${ }^{34}$ R. Sobański, Kościót jako podmiot prawa, s. 190-191. 
ty kontynent amerykański ${ }^{35}$. Stanowiskiem pośredniej władzy Kościoła w porządku doczesnym zaczęli zajmować się Robert Bellarmin (†1621) oraz Franciszek Suarez (†1617). Wypracowali oni następujące zasady, na których opierała się ta teoria:

ludzkość została poddana jednocześnie dwom władzom - kościelnej i państwowej - na zasadzie równości [...]; zasada odpowiedzialności wszystkich ludzi - zarówno poszczególnych jednostek ludzkich, jak i społeczności oraz władz państwowych - wobec Boga, przez którego Kościół jest upoważniony do reprezentowania Go, nauczania prawd objawionych i ochrony prawa Bożego: naturalnego i objawionego [...]; konieczność ustanowienia pozytywnych norm wyznaczających relacje między Kościołem i państwem, czyli między suwerennymi władzami każdej z tych społeczności, ze względu na związek między nimi w sprawach mieszanych, które ze swej natury wchodzą w zasięg obu społeczności [...]) w przypadku konfliktu $\mathrm{w}$ tych sprawach mieszanych ostateczny sąd należy do władzy kościelnej, gdyż chodzi o dobro i zbawienie dusz ${ }^{36}$.

Po załamaniu się systemu jedności prawa prawo kanoniczne po Soborze Trydenckim zostaje już tylko wewnętrznym prawem Kościoła, stanowiąc jednak podstawę do obrony własnej niezależności i równorzędności względem prawa świeckiego. W eklezjologii akcentuje się cechy Kościoła jako podobne do cech państwa, a podstawowe pojęcia prawne kształtują się pod wpływem świeckiej myśli prawniczej. Różnice między prawem kanonicznym i świeckim widoczne są na przykładzie różnic między wspólnotami religijną i świecką. Wyrazem dążenia do zrównania prawa kościelnego ze świeckim jest pragnienie kodyfikacji prawa kościelnego $^{37}$.

Kolejnym etapem w relacjach państwo-Kościół było zrodzenie się nowego typu państwa, zwanego świeckim. Nastąpiło to po rewolucji francuskiej, która przyczyniła się do utworzenia nowych idei filozoficznych i ideologicznych, a także jako jeden z głównych celów przyjęła oddzielenie

35 W. Góralski, Wstęp do prawa wyznaniowego, s. 20-21.

${ }^{36}$ J. Krukowski, Kościelne prawo publiczne, s. 43-44.

37 R. Sobański, Prawo kościelne a prawo świeckie, s. 65-77. 
sfery państwowej od religijnej. Zasada pośredniej władzy Kościoła nie mogła się już obronić ${ }^{38}$.

W okresie od XVIII do XX wieku w relacjach państwo-Kościół ukształtowały się nowe systemy, takie jak rozdział Kościoła od państwa (separacja wroga: francuska i sowiecka - totalitarna, czysta - amerykańska, skoordynowana - niemiecka) oraz państwa wyznaniowe.

Systemy państw świeckich posiadają dwa elementy, negatywny oraz pozytywny. Jeśli chodzi o element negatywny, to oznacza on, iż państwa świeckie nie uznają żadnej religii jako państwowej, a żaden Kościół nie jest oficjalnym. Co do elementu pozytywnego, to dotyczy on zasady równości wszystkich Kościołów względem prawa. Nie ma jednego konkretnego modelu państwa świeckiego, powszechnie jako wyznacznik przyjmuje się zasadę separacji państwa od Kościoła. Są różne modele takiej separacji i możemy wyróżnić ich trzy rodzaje: amerykański model separacji czystej, model separacji wrogiej w wersji francuskiej i sowieckiej oraz model separacji skoordynowanej w wersji niemieckiej, który po pewnych modyfikacjach został wprowadzony do większości współczesnych państw europejskich $^{39}$.

Jeśli chodzi o model separacji czystej, to powstał on w USA, a jego głównym celem było pokojowe rozwiązanie sporów na tle wielkiego pluralizmu kulturowego i religijnego. Za jego formalny początek uważany jest rok 1789, kiedy to wprowadzono do Konstytucji USA pierwszą poprawkę, która zawierała zakaz ustanawiania religii państwowej, a także nadawania jakiejkolwiek religii charakteru oficjalnego. Ponadto poprawka ta zawierała także zakaz ograniczania swobody praktyk religijnych ${ }^{40}$.

Model separacji wrogiej występuje w dwóch wersjach: skrajnie liberalnej - francuskiej oraz totalitarnej - sowieckiej.

Francuska powstała podczas rewolucji francuskiej (1789-1795). Ścisła unia między tronem i ołtarzem - gallikanizm. We Francji była monarchia absolutna. Ostrze rewolucji skierowało się w Kościół, bo był utożsamiany z władzą polityczną. W 1801 roku został podpisany konkordat napoleoński. W XIX wieku Kościół w mniejszym lub większym

\footnotetext{
38 W. Góralski, Wstęp do prawa wyznaniowego, s. 22.

39 A. Mezglewski, Systemy relacji państwo-Kościół w ujęciu historycznym, s. 17-22.

${ }^{40}$ H. Misztal, Systemy relacji państwo-Kościół, s. 44-45.
} 
stopniu prześladowano. W roku 1905 osiągnęło to apogeum, w czasie którego wydano ustawę o separacji. Kościół pozbawiono osobowości prawnej i zrównano ze zwykłym stowarzyszeniem. Nastąpiła prywatyzacja religii (zakaz jej uzewnętrzniania). W tej ustawie faworyzowano ateistów i agnostyków. W trzech departamentach francuskich istnieje system konkordatowy: Dolny Ren, Górny Ren, Mozela ${ }^{41}$.

Sowiecka - państwo wyznaniowe à rebours (arabe). Państwo wyznaniowe na opak - na odwrót. W miejsce religii oficjalnej wprowadza się ideologię (marksizm, leninizm). W 1918 roku wydano Dekret Komisarzy Ludowych o oddzieleniu Kościoła od państwa i szkoły od Kościoła. Podobne zasady zawarto w Konstytucji Stalina z 1936 roku. Komuniści uważali, że religia stanowi opium dla mas, chcieli budować raj na zie$\mathrm{mi}$, a religia im w tym przeszkadzała. W tym celu wprowadzono kasatę zakonów, przejęto majątek kościelny, zlaicyzowano szkolnictwo. Model ten został wprowadzony po II wojnie światowej w Europie Środkowo-Wschodniej ${ }^{42}$.

Ostatnim modelem separacji państwa od Kościoła jest model separacji skoordynowanej. Pojawił się on w Niemczech po I wojnie światowej na mocy zapisu w Konstytucji weimarskiej z 1919 roku. Chodziło o art. $137 \$ 1$, w którym zapisano, iż nie ma Kościoła oficjalnego, a także o art. 136, gwarantujący wolność religijną jako podstawowe prawo każdego człowieka $^{43}$. Odmienność tej separacji od amerykańskiej czy francuskiej polega na tym, iż uznaje ona osobowość publicznoprawną Kościołów zakorzenionych w tradycję narodową. „Z postanowień konstytucyjnych Niemiec wynikają następujące konsekwencje: każdy Kościół jest autonomicznym podmiotem zdolnym do stanowienia dla siebie norm prawnych i do samodzielnego decydowania o swej działalności na terenie państwa; sprawy interesujące Kościół i państwo mają być rozstrzygane w drodze dwustronnych układów, będących źródłem prawa" ${ }^{44}$. Po II wojnie światowej Niemiecka Republika Federalna utrzymała postanowienia dotyczące spraw wyznaniowych z poprzedniej konstytucji.

\footnotetext{
${ }^{41}$ J. Krukowski, Polskie prawo wyznaniowe, s. 31-32.

42 Tamże, s. 32-33.

43 A. Mezglewski, Systemy relacji państwo-Kościót w ujęciu historycznym, s. 22-23.

${ }^{44}$ J. Krukowski, Polskie prawo wyznaniowe, s. 30-33.
} 
Jeśli chodzi o państwa wyznaniowe, to występowały w dwóch wersjach, tradycyjnej i zmodernizowanej. Charakterystyczne dla wersji tradycyjnej było to, iż państwo potwierdzało doktrynę religijną jako jedynie prawdziwą, uznając daną religię jako oficjalną, subwencjonując ją oraz zakazując wyznawania innych. Natomiast w wersji zmodernizowanej państwa wyznaniowego nie było afirmacji przez państwo jakiejś religii jako prawdziwej, ale było uznanie jej za oficjalną religię danego narodu i subwencjonowanie jej, przy zachowaniu gwarancji wolności religijnych wyznawcom innych religii ${ }^{45}$. Państwa wyznaniowe związane $\mathrm{z}$ religią katolicką istniały tylko do Soboru Watykańskiego II.

\section{WSPÓŁCZESNE SYSTEMY RELACJI PAŃSTWO-KOŚCIÓŁ W ŚWIETLE NAUCZANIA SOBORU WATYKAŃSKIEGO II}

Zmiany zachodzące w świecie spowodowały potrzebę odnowy nauki Kościoła oraz dopasowania jej do potrzeb czasów współczesnych. Dlatego to głównym celem Soboru Watykańskiego II była odnowa oraz dostosowanie instytucji kościelnych i metod działania Kościoła do tychże zmian. Bardzo ważnym aspektem tej odnowy stała się relacja na linii państwo-Kościół. Potrzeba było odświeżenia, a także dostosowania tej relacji do czasów współczesnych. Owoce tej dyskusji znajdują się w następujących dokumentach: Konstytucji dogmatycznej o Kościele Lumen gentium, Konstytucji duszpasterskiej o Kościele w świecie współczesnym Gaudium et spes, Deklaracji o wolności religijnej Dignitatis humanae, Deklaracji o wychowaniu chrześcijańskim Gravissimum educationis, Dekrecie o pasterskich zadaniach biskupów w Kościele Christus Dominus, Dekrecie o apostolstwie świeckich Apostolicam actuositatem ${ }^{46}$.

W duchu odnowy soborowej nie można postrzegać relacji Kościoła do świata tylko w kategoriach prawnych. Takie kategorie dotyczą Kościoła tylko wtedy, kiedy ma do czynienia z rzeczywistością doczesną, prawnie zorganizowaną, jaką stanowi państwo. $Z$ dokumentów soborowych jasno wynika, że zarówno Kościół, jak i wspólnota polityczna (państwo) są

${ }^{45}$ W. Góralski, Wstęp do prawa wyznaniowego, s. 25-27.

${ }^{46}$ Sobór Watykański II, Konstytucje, Dekrety, Deklaracje; tekst polski, Poznań 2002. 
w swoich dziedzinach od siebie niezależne i autonomiczne. Kościół nie utożsamia się z żadną wspólnotą i systemem politycznym. Kościół i państwo, według nauczania Soboru Watykańskiego II, działają na wspólnej płaszczyźnie wtedy, gdy chodzi o dobro człowieka i to zarówno w wymiarze indywidualnym, jak i społecznym. Punktem wyjścia jest to, iż człowiek należy jednocześnie do obu wspólnot ${ }^{47}$.

Sobór Watykański II odmienił stanowisko Kościoła wobec relacji państwo-Kościół. Otóż zgodnie z założeniami dualizmu chrześcijańskiego należało rozróżnić wspólnotę polityczną od państwowej, przy zachowaniu współpracy między nimi. Jednak do czasu soboru Kościół podkreślał wymóg nadawania państwom charakteru wyznaniowego. Tam, gdzie katolicy stanowili większość ludności, państwo powinno mieć charakter katolicki, a Kościołowi należało zagwarantować wolność. Pozostałe wspólnoty religijne powinny być tylko tolerowane. Nowością w nauczaniu soborowym jest to, iż w relacji państwo-Kościół punktem wyjścia przestała być idea państwa wyznaniowego, ale stał się fakt istnienia społeczeństwa pluralistycznego, w którym Kościół istnieje obok innych wspólnot religijnych i żadnej z nich nie przysługuje uprzywilejowana pozycja ${ }^{48}$.

Podstawą takiej zmiany w nauczaniu Kościoła stały się trzy fundamentalne zasady zawarte $\mathrm{w}$ dokumentach soborowych, a są nimi:

1. Zasada poszanowania wolności sumienia i religii, jako prawa należnego każdemu człowiekowi z racji przyrodzonej godności osoby ludzkiej i wolności należnej każdej wspólnocie religijnej, bez jakichkolwiek przywilejów ${ }^{49}$;

2. Zasada poszanowania autonomii Kościoła i państwa, należnej każdemu w swoim porządku, tzn. państwu w porządku doczesnym, a Kościołowi i innym wspólnotom religijnym w porządku duchowym, czyli religijno-moralnym ${ }^{50}$;

3. Zasada współdziałania między Kościołem, jako wspólnotą religijną, i państwem, jako wspólnotą polityczną, dla dobra wspólnego tych samych ludzi, którzy jednocześnie, chociaż pod

47 W. Góralski, Wstęp do prawa wyznaniowego, s. 22.

48 J. Krukowski, Polskie prawo wyznaniowe, s. 34.

49 A. Miziński, Relacje między państwem a Kościołem na Soborze Watykańskim II, s. 58-63.

50 Tamże, s. 64-70. 
innymi względami, przynależą do każdej z nich. To współdziałanie ma na celu budowanie takiego ładu moralnego i porządku prawnego, w którym są uznawane i chronione prawa i wolności należne każdemu człowiekowi ${ }^{51}$.

Powyższe zasady wypracowane przez Ojców soborowych ukazują pragnienie Kościoła, aby współistnieć na równi ze wspólnotami politycznymi. Zasady te mają charakter uniwersalnych postulatów i zostały skierowane nie tylko do katolików, ale także i do tych, którzy odpowiadają za systemy państwowe, czyli do polityków, bez względu na ich przynależność partyjną. Czyniąc refleksję historyczną, należy zauważyć, iż stały się one podstawą do rewizji systemów prawnych dotyczących relacji państwo i związki wyznaniowe, zwłaszcza w państwach, które przeszły od systemów państw wyznaniowych do świeckich ${ }^{52}$.

\section{ZAKOŃCZENIE}

Analiza przedstawionego materiału pozwoliła na dokonanie refleksji prawno-historycznej dotyczącej relacji miedzy Kościołem a państwem. Nauka Kościoła wprowadziła nowość w postaci dualizmu chrześcijańskiego do systemów politycznych. Nie było to łatwe zadanie, gdyż na przestrzeni dziejów zarówno ze strony państwa, jak i Kościoła pojawiały się tendencje do supremacji jednej wspólnoty nad drugą i pod pretekstem zachowania porządku dualistycznego dążono do wprowadzenia antycznego monizmu. Jasne stanowisko Kościoła, zaprezentowane na Soborze Watykańskim II, pozwoliło na unormowanie tychże relacji oraz wyznaczyło miejsce zarówno wspólnoty kościelnej, jak i politycznej we wzajemnych relacjach. Nauka soborowa nie jest jednak żadnym novum, gdyż tak naprawdę realizuje zamysł założyciela Kościoła - Chrystusa.

Streszczenie. Kościół i państwo to dwie wspólnoty, w skład których wchodzą te same osoby. Nie da się zatem oddzielić tych wspólnot od siebie. Każda z nich ma oddzielny cel. Głównym zadaniem Kościoła jest służba ludziom i niesienie pomocy w osiągnięciu podstawowych wartości religijnych i etycznych, a także doprowadzenie

${ }^{51}$ Tamże, s. 70-73.

${ }^{52}$ J. Krukowski, Kościół i państwo, s. 22 
każdego ze swoich członków do zbawienia. Państwo to społeczność utworzona przez ludzi, zazwyczaj należących do tej samej wspólnoty kulturowej, której celem jest zaspokojenie swoich potrzeb doczesnych. Dlatego zaistniała potrzeba ustalenia właściwej relacji miedzy Kościołem a państwem jako społecznościami odmiennej natury. W niniejszym opracowaniu opisano, w jaki sposób relacje państwo-Kościół kształtowały się na przestrzeni dziejów, od czasu pojawienia się chrześcijaństwa aż do czasów współczesnych.

Słowa kluczowe: relacje państwo-Kościół; państwo wyznaniowe; państwo świeckie; rozdział państwa od Kościoła.

\section{Abstract. Forming Relations Between the Country and the Church. The Legal-} -Historical Aspect. The Church and the state are two communities inhabited by the same people. They can not be divided. Each of them has the separate objective. The main task of the Church is to serve people, give them help to achieve basic religious and ethical values and lead every member of the community to salvation. State is the community created by people who usually belong to the same cultural community whose objective is to satisfy their temporal needs. That is why there is a need to establish an appropriate relation between the Church and the state, as communities with different natures, arose. This paper describes the way the relations between the state and the Church have been formed over history, from the beginning of Christian era up to date.

Key words: state-Church relations; denominational state; secular country; state-Church separation.

\section{BIBLIOGRAFIA}

Apostolicam actuositatem, 18.11.1965, w: Sobór Watykański II, Konstytucje, Dekrety, Deklaracje; tekst polski, Poznań 2002, s. 377-401.

Banaszak M., Historia Kościoła Katolickiego, t. 1, Warszawa 1989.

Christus Dominus, 28.10.1965, w: Sobór Watykański II, Konstytucje, Dekrety, Deklaracje; tekst polski, Poznań 2002, s. 236-258.

Dignitatis humanae, w: Sobór Watykański II, Konstytucje, Dekrety, Deklaracje; tekst polski, Poznań 2002, s. 410-421.

Gaudium et spes, 7.12.1965, w: Sobór Watykański II, Konstytucje, Dekrety, Deklaracje; tekst polski, Poznań 2002, s. 526-606.

Góralski W., Wstęp do prawa wyznaniowego, Płock 2003.

Gravissimum educationis, w: Sobór Watykański II, Konstytucje, Dekrety, Deklaracje; tekst polski, Poznań 2002, s. 314-323.

Krukowski J., Kościelne prawo publiczne. Prawo konkordatowe, Lublin 2013.

Krukowski J., Kościół i państwo. Podstawy relacji prawnych, Lublin 1993.

Krukowski J., Polskie prawo wyznaniowe, Warszawa 2008. 
Lumen gentium, 21.11.1964, w: Sobór Watykański II, Konstytucje, Dekrety, Deklaracje; tekst polski, Poznań 2002, s. 104-166.

Mezglewski A., Systemy relacji państwo-kościół w ujęciu historycznym, w: Prawo wyznaniowe, red. A. Mezglewski, H. Misztal, P. Stanisz, wyd. 3, Warszawa 2011.

Misztal H., Systemy relacji państwo-kościót, w: Prawo wyznaniowe, red. H. Misztal, P. Stanisz, wyd. 2, Lublin 2003.

Miziński A., Relacje między państwem a kościołem na Soborze Watykańskim II, w: Katolickie zasady relacji państwo-kościół a prawo polskie, red. J. Krukowski, M. Sitarz, H. Stawniak, Lublin 2015.

Pismo Święte Starego i Nowego Testamentu (Biblia Tysiąclecia), wydanie piąte, Poznań 2005.

Rahner K., Kościół i prawo we wczesnym chrześcijaństwie, Warszawa 1986.

Sobański R., Kościót jako podmiot prawa, Warszawa 1983.

Sobański R., Prawo kościelne a prawo świeckie, „Prawo Kanoniczne” 30 (1987) 3-4, s. $63-74$. 